\title{
Biodiversity Conservation in the REDD
}

\author{
Gary D Paoli ${ }^{1 *}$, Philip L Wells ${ }^{1}$, Erik Meijaard ${ }^{2,3}$, Matthew J Struebig ${ }^{4,5}$, Andrew J Marshall ${ }^{6}$, Krystof Obidzinski ${ }^{7}$, \\ Aseng Tan ${ }^{8}$, Andjar Rafiastanto ${ }^{8}$, Betsy Yaap ${ }^{1}$, JW Ferry Slik ${ }^{9}$, Alexandra Morel ${ }^{10}$, Balu Perumal ${ }^{11}$, Niels Wielaard ${ }^{12}$, \\ Simon Husson ${ }^{13}$, Laura D'Arcy ${ }^{13}$
}

\begin{abstract}
Deforestation and forest degradation in the tropics is a major source of global greenhouse gas (GHG) emissions. The tropics also harbour more than half the world's threatened species, raising the possibility that reducing GHG emissions by curtailing tropical deforestation could provide substantial co-benefits for biodiversity conservation. Here we explore the potential for such co-benefits in Indonesia, a leading source of GHG emissions from land cover and land use change, and among the most species-rich countries in the world. We show that focal ecosystems for interventions to reduce emissions from deforestation and forest degradation in Indonesia do not coincide with areas supporting the most species-rich communities or highest concentration of threatened species. We argue that inherent trade-offs among ecosystems in emission reduction potential, opportunity cost of foregone development and biodiversity values will require a regulatory framework to balance emission reduction interventions with biodiversity co-benefit targets. We discuss how such a regulatory framework might function, and caution that pursuing emission reduction strategies without such a framework may undermine, not enhance, long-term prospects for biodiversity conservation in the tropics.
\end{abstract}

\section{Introduction}

Carbon emissions from deforestation and forest degradation contribute $12-20 \%$ of anthropogenic global greenhouse gas (GHG) emissions annually $[1,2]$, primarily from the tropics [3]. Tropical countries also harbour over half (51.1\%) of the world's 48,170 threatened species [4], raising the possibility that reducing GHG emissions by curtailing tropical deforestation might also provide valuable co-benefits for biodiversity conservation [5]. Here we explore potential biodiversity impacts of anticipated emission reduction strategies in Indonesia, the world's third largest source of GHG emissions [6] and among the most species-rich countries in the world. We address calls in this journal $[7,8]$ and elsewhere [9-11] for a stronger regulatory framework governing emission reduction strategies in forests to ensure that biodiversity co-benefits are achieved. We caution that in Indonesia and other tropical countries, pursuing emission reduction strategies in forests without such a framework may worsen, not enhance, long-term biodiversity conservation.

\footnotetext{
* Correspondence: gary.paoli@daemeter.org

'Daemeter Consulting, Bogor, Indonesia

Full list of author information is available at the end of the article
}

The Reducing Emissions from forest Degradation and Deforestation (REDD) scheme of the post-Kyoto UN Framework Convention on Climate Change (UNFCCC) treaty seeks to involve developing countries in global GHG reduction efforts by creating financial incentives to improve forest management and protection [12]. Under REDD, and its derivative REDD+, which recognizes forest carbon stock enhancements (sequestration) from improved conservation and sustainable management of forests, developing countries that reduce forest based emissions below an established 'business as usual' projection will be rewarded through payments from donor funds or market sale of emission reduction credits.

REDD clearly provides an opportunity for biodiverse, carbon-rich tropical countries to protect threatened biodiversity as a co-benefit of maintaining forests and the carbon they store $[11,13]$. However, it remains unclear how biodiversity provisions will be included within REDD, raising questions about the extent to which it will improve biodiversity conservation over the long-term $[5,14,15]$. Estimated terrestrial carbon and biodiversity are positively correlated globally [11], but this pattern does not necessarily hold at sub-national scales where REDD will typically be implemented. This raises concern 
that preferential targeting of carbon-rich ecosystems may intensify pressures on relatively carbon-poor ecosystems that nevertheless support equal or greater levels of biodiversity [15-17].

\section{Discussion \\ REDD in Indonesia}

Indonesia, where REDD will be pursued as a set of subnational programs, illustrates the need for explicit biodiversity provisions to ensure that biodiversity co-benefits are achieved, and unanticipated negative outcomes are avoided.

Indonesia is a rapidly growing developing country, with economic growth of $4.5-6.3 \%$ annually over the past three years [18] due in part to expanding natural resource industries such as oil palm, fiber plantations and pulp. Continued growth of these sectors is central to government plans to expand exports and create jobs. The Ministry of Forestry recently announced a 10-year plan to develop nine million ha of fiber plantations to supply a two-fold expansion of pulp and paper capacity [19]. Similarly, up to 10 million ha of new oil palm plantations are projected for development by 2020 to meet growing demand for palm oil derived products [20,21]. Together, these industries will require an estimated 19 million ha of land for new plantations over the next 10 years.

Plantation expansion notwithstanding, Indonesia has also made voluntary commitments to reduce emissions by $26 \%$ by 2020 , or up to $41 \%$ if financial support is forthcoming from the international community [22]. Such commitments have drawn significant attention, including a recent offer from Norway of US $\$ 1$ billion to Indonesia for assistance with implementing REDD [23], and up to 45 REDD projects under development as of early $2010[24,25]$.

\section{Sources of forest based emissions in Indonesia}

Approximately $85 \%$ of Indonesia's estimated $3.01 \mathrm{Gt}$ $\mathrm{CO}_{2}$ annual emissions in 2005 originated from deforestation and degradation [6]. The main sources of these emissions are lowland dipterocarp forests on welldrained mineral soils and peat swamp forest on waterlogged peatlands, with estimated original extent of c. 128.1 million ha and c. 20.1 million ha, respectively (Table 1). Estimated aboveground carbon is similar in forests on mineral soils and peat $(211 \pm 55$ vs. $230 \pm 66$ t C ha ${ }^{-1}$, respectively, mean $\pm \mathrm{SD}$; Table 1 , see Additional File 1: Datafile_1.xls for original data). However, belowground carbon stocks differ markedly, with up to c. 20 times more carbon in the un-decomposed organic matter of peat compared to mineral soils $(137 \pm 26$ vs $2425 \pm 726 \mathrm{t} \mathrm{C} \mathrm{ha}^{-1}$; Table 1). Total carbon stocks are thus, on average, eight times higher in lowland forests on peat than on mineral soils, with corresponding higher total estimated GHG emissions arising from their conversion (Table 1).

Historically, deforestation rates on peat were much lower than on mineral soils, reflecting higher costs, lower yield and technological challenges of developing peatlands [62]. From 1985-1997, relative losses of lowland forest on mineral soils in Sumatra and Kalimantan were nearly three times higher than forests on the coastal alluvial plains dominated by peat ( $61 \%$ vs $24 \%$ in Sumatra; $58 \%$ vs $23 \%$ in Kalimantan; data from [63]).

Increased use of technology, however, such as excavators, coupled with expanding trade and rising demand for land have stimulated large-scale drainage of forested peatlands for transmigration projects and agricultural development [64-66]. Drainage and resulting oxidation of carbon-dense peat, combined with annual fires $[60,61]$, made peat the source of nearly half $(45 \%, 1.35$

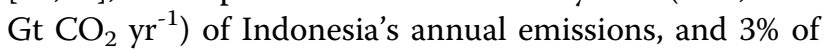
global emissions, in 2005 (Table 1; [6,67]). Further, destructive synergies with extreme drought linked to El Nino Southern Oscillation increase risk of catastrophic fires, such as the 1997-98 peat land fires in Kalimantan that caused emissions estimated to represent $13-40 \%$ of global emissions originating from fossil fuels during that period [68].

\section{Reconciling plantation expansion with emissions reduction}

One option to expand plantations and meet emission reduction targets in Indonesia would be to concentrate new plantations on degraded, deforested land, of which c. 23 million ha in critical condition were mapped across Indonesia in 2006 [69]. Planting such 'degraded lands' has proven to be a challenge, however, due to the scarcity of land meeting an ecologically and socially sound definition of degraded, and the fact that much deforested land is in fact under some form of management by local communities.

Given the much higher total carbon storage (emission reduction potential) of forests on peat (Table 1), and lower opportunity cost of foregoing peatland development, limiting further conversion of peat would seem a preferred means to reconcile economic growth and emissions reduction. Indeed, the Indonesian government recently expressed this view [70]; Norway has made it a pre-condition of its $\$$ US1 billion offer [23]; and peatlands, despite their lesser extent than mineral areas (Table 1), have drawn the majority of REDD project investments, with 11 of 17 site-based carbon projects in Sumatra and Kalimantan on peat, equal to 1.69 million (56\%) of the estimated 3.06 million ha of REDD projects across Indonesia (see Additional File 2: Datafile_2.pdf). 
Table 1 Physical attributes and emission estimates for lowland tropical forest ( $<500 \mathrm{~m}$ a.s.l.) on peat and mineral substrates in Indonesia

\begin{tabular}{|c|c|c|}
\hline \multirow[t]{2}{*}{ Lowland forest on } & \multirow[t]{2}{*}{ ontrasting substrates } & \multirow[b]{2}{*}{ Peat } \\
\hline & & \\
\hline (a) Estimated original extent in Indonesia (1000 ha) ${ }^{a}$ & 128,100 & 20,949 \\
\hline \multicolumn{3}{|l|}{ (b) Carbon Stocks (mean \pm sd; range) } \\
\hline Aboveground stocks $\left(\mathrm{t} C \mathrm{ha}^{-1}\right)^{\mathrm{b}}$ & $211 \pm 55(100-370)$ & $230 \pm 66(148-3510)$ \\
\hline Belowground stocks (t $\left.\mathrm{C} \mathrm{ha}{ }^{-1}\right)$ & $137 \pm 26(98-168)^{c}$ & $2425 \pm 726(600-3131)^{d}$ \\
\hline Total (t C ha $\left.{ }^{-1}\right)$ & $353(214-539)$ & $2680(748-3496)$ \\
\hline \multicolumn{3}{|l|}{ (c) $\mathrm{CO}_{2}$ emissions ( $\mathrm{CO}_{2} \mathrm{ha}^{-1} \mathrm{yr}^{-1}$ ) } \\
\hline Estimated net annual $\mathrm{CO}_{2}$ emissions from oil palm plantations (mean $\pm \mathrm{sd}$; range) ${ }^{\mathrm{e}}$ & $13.7 \pm 5.6(8.1-25.3)$ & $58.6 \pm 18.2(43.7-87.0)$ \\
\hline Estimated net annual $\mathrm{CO}_{2}$ emissions from fiber plantations ${ }^{\mathrm{f}}$ & 16.6 & 48.4 \\
\hline $\begin{array}{l}\text { Estimated total annual } \mathrm{CO}_{2} \text { emissions from deforestation and degradation across Indonesia } \\
\text { (range) }{ }^{\mathrm{g}}\end{array}$ & 538-1596 & $2121-4611$ \\
\hline \multicolumn{3}{|c|}{$\begin{array}{l}\text { (d) Estimated original extent of lowland forest in Kalimantan and occurrence of remaining forest as of } 2008 \text { in different land use classes according to } \\
\text { national spatial plans (percentage of total remaining area in parentheses) }\end{array}$} \\
\hline Estimated original extent (ha) & $39,921,309$ & $4,321,178$ \\
\hline Estimated remaining extent as of 2008 (ha) & $21,508,044$ & $2,382,313$ \\
\hline - Forest allocated for Protection & $3,663,783(17.0)$ & $195,606(8.2)$ \\
\hline - Forest allocated for Production & $12,429,890(57.8)$ & $1,268,977(53.3)$ \\
\hline - Forest allocated for Conversion & $5,414,371(25.2)$ & $917,730(38.5)$ \\
\hline
\end{tabular}

Comparisons are made between (a) estimated original extent of forest on peat and mineral substrates across Indonesia; (b) carbon stocks and (c) emission levels from both Kalimantan and Sumatra; and (d) estimated original and remaining 2008 lowland forest cover in Kalimantan on peat and mineral soil, separated by national land use classification.

${ }^{a}$ Estimated extent of 2008 forest cover derived from SPOT Veg imagery ( $1 \mathrm{~km}^{2}$ resolution) by SarVision, overlaid with SRTM to define areas <500 m a.s.I. [26] and Wetlands International map of peat lands to define areas with surface peat $>50 \mathrm{~cm}$ depth [27-29]. Total extent of lowland forest on mineral soils was estimated as all other forest $<500 \mathrm{~m}$ a.s.l. not on peat, and includes lowland rain forest on well drained mineral soils (c. 107 of $128 \mathrm{million}$ ha, $84 \%$ of the total], as well as forest on limestone, ultrabasic rock, nutrient poor sandy soils on which kerangas (heath) forest develops, mangroves and freshwater swamps.

b See Additional File 1: Datafile_1.xls; [30-49].

c Data from [50].

d Data from [13,51-53].

e See Additional File 1: Datafile_1.xls; [54-58].

f Data from [55].

${ }^{\mathrm{g}}$ Includes emissions originating from deforestation, degradation, peat land decomposition from drainage and fires; data from [59-61].

h Using data for lowland forest on mineral soils described under note (a), the forest area for Kalimantan was further subdivided according to land use status as defined by the Indonesian Ministry of Forestry (Tata Guna Hutan Kesepakatan, TGHK). Protection Forest areas are allocated for conservation purposes and may not be exploited; Production Forest areas may be logged and/or converted to industrial wood fiber plantations but not agriculture; Conversion Forest areas are allocated for planned conversion to non-forest agricultural crops (including e.g. oil palm or rubber).

\section{Unexpected outcomes for biodiversity}

Tropical lowland forests on peat or mineral soils are priority areas for biodiversity conservation, yet are typically underrepresented in protected area networks relative to upland habitats [72]. Greater protection of Indonesian peatlands under REDD therefore would not only achieve emission reductions, but also help conserve a unique ecosystem that supports specialized aquatic and plant biodiversity [73-76], and provides wilderness habitat for some of Indonesia's most endangered large vertebrates, including Sumatran tigers, Asian elephants, orangutan and false gharial [77-80]. Nevertheless, if REDD is implemented with a disproportionate focus on peat, and Indonesia pursues goals for 19 million ha of new plantations over the next 10 years, then the potential for REDD to promote conservation for the majority of Indonesia's threatened species will not have been realized. Worse yet, REDD could effectively increase pressure to convert lowland mineral forest areas. This will severely limit biodiversity co-benefits of REDD in Indonesia, and risk undermining efforts to conserve biodiversity in the long-term, for three reasons.

First, overall biodiversity levels in peat forest are substantially lower than in lowland forest on mineral soils [81-83], reflecting the water-logged, nutrient-poor status and lower productivity of peat forests [84-86]. Peat forest plant diversity is less than half that of forest on mineral soils (Table 2; see Additional File 1: Datafile_1.xls for original data). Only 21 (15\%) of Indonesia's 140 Critically Endangered lowland plant species have been recorded in peat, including three as specialists, compared to 104 (74\%) found in lowland forest on mineral soils, 84 as specialists (Table 2; see Additional File 3: Datafile_3.xls for original data). Peat forests also harbour significantly 
Table 2 Biodiversity attributes of lowland tropical forest ( $<500 \mathrm{~m}$ a.s.l.) on peat and mineral soil substrates in Sumatra and Kalimantan, Indonesia

\section{Lowland forest on contrasting substrates}

Taxon and Attribute

Mineral soils ${ }^{\text {a }} \quad$ Peat

(a) Woody plants

Species richness (number species per 100 stems) ${ }^{b}$

Fisher's alpha

Critically Endangered species recorded present in forest on each substrate ${ }^{c}$

$35.2 \pm 5.6 * * *$

$15.1 \pm 4.0$

$80.9 \pm 10.7$ ***

$18.2 \pm 6.2$ (b) Bats

\begin{tabular}{|c|c|c|}
\hline Species richness (rarefied number species at standard sample) ${ }^{d}$ & $16.6 \pm 1.3 *$ & $11.6 \pm 0.8$ \\
\hline Bat density (total abundance per trap night) & $5.5 \pm 2.7 *$ & $2.0 \pm 0.5$ \\
\hline \multicolumn{3}{|l|}{ c) Densities of vertebrate species ${ }^{e}$} \\
\hline Water monitor Varanus salvator & $0.22 \pm 0.15 *$ & $0.00 \pm 0.00$ \\
\hline Sun Bear Helarctos malayanus & $0.06 \pm 0.07$ & $0.00 \pm 0.00$ \\
\hline Slow loris Nycticebus coucang & $0.03 \pm 0.06$ & $0.00 \pm 0.00$ \\
\hline Helmeted hornbill Rhinoplax vigil & $0.03 \pm 0.06$ & $0.00 \pm 0.00$ \\
\hline Small toothed palm civet Arctogalidia trivirgata & $0.03 \pm 0.06$ & $0.00 \pm 0.00$ \\
\hline Pangolin Viverra tangalunga & $0.03 \pm 0.06$ & $0.00 \pm 0.00$ \\
\hline Long tail macaque Macaca fascicularis & $1.07 \pm 0.41^{* * *}$ & $0.11 \pm 0.16$ \\
\hline Barking deer Muntiacus muntjak & $0.62 \pm 0.26 *$ & $0.11 \pm 0.16$ \\
\hline Bushy crested hornbill Anorrhinus galeritus & $0.47 \pm 0.21 *$ & $0.11 \pm 0.16$ \\
\hline Red leaf monkey Presbytis rubicunda & $2.32 \pm 0.54 * * *$ & $0.62 \pm 0.47$ \\
\hline Rhinoceros hornbill Buceros rhinoceros & $0.45 \pm 0.25$ & $0.17 \pm 0.19$ \\
\hline Tufted ground squirrel Rheithrosciurus macrotis & $0.20 \pm 0.17$ & $0.11 \pm 0.16$ \\
\hline Monitor lizard Varanus sp. & $0.15 \pm 0.13$ & $0.11 \pm 0.16$ \\
\hline Bornean white bearded gibbon Hylobates albibarbis & $3.68 \pm 0.77$ & $2.87 \pm 0.87$ \\
\hline Pale giant squirrel Ratufa affinis & $0.65 \pm 0.29$ & $0.56 \pm 0.34$ \\
\hline Oriental pied hornbill Anthracoceros albirostris & $0.59 \pm 0.30$ & $0.68 \pm 0.40$ \\
\hline Bornean bearded pig Sus barbatus & $2.27 \pm 0.58$ & $2.65 \pm 0.78$ \\
\hline Bornean orangutan Pongo pygmaeus & $0.98 \pm 0.41$ & $1.32 \pm 0.65$ \\
\hline Mouse deer Tragulus spp. & $0.28 \pm 0.17$ & $0.39 \pm 0.29$ \\
\hline Pig tail macaque Macaca nemestrina & $0.11 \pm 0.11$ & $0.17 \pm 0.19$ \\
\hline Prevost squirrel Callosciurus prevostii & $0.17 \pm 0.13$ & $0.39 \pm 0.29$ \\
\hline Binturong Arctictis binturong & $0.06 \pm 0.08$ & $0.17 \pm 0.19$ \\
\hline Wreathed hornbill Aceros undulatus & $0.00 \pm 0.00$ & $0.06 \pm 0.11$ \\
\hline \multicolumn{3}{|l|}{ d) Densities of large vertebrate Orders } \\
\hline Artiodactyla (deer and pigs) & $3.17 \pm 0.71$ & $3.15 \pm 0.85$ \\
\hline Primata (primates) & $8.20 \pm 1.40 *$ & $5.09 \pm 1.24$ \\
\hline Bucerotidae (hornbills) & $1.61 \pm 0.51$ & $1.01 \pm 0.49$ \\
\hline Carnivora (carnivores) & $0.17 \pm 0.14$ & $0.16 \pm 0.20$ \\
\hline
\end{tabular}

Comparisons are made between (a) woody plants, (b) bats, and (c \& d) large vertebrates. Plant data compiled from published and unpublished literature, and mammal data are derived from field surveys. All data are mean $\pm 95 \% \mathrm{Cl}$.

. $P<0.05,{ }^{* *} P<0.01,{ }^{* * *} P<0.001$

${ }^{a}$ Forest on lowland mineral (non-swamp) soils excluding forest on limestone, ultrabasic rock and coarse textured sandy soil types on which kerangas vegetation develops.

${ }^{\mathrm{b}}$ Compilation of published and unpublished records of 'local scale' (defined as $<3$ ha total sample plot area) woody plant surveys for stems $\geq 10 \mathrm{~cm}$ diameter at breast height (see Additional File 1: Datafile_1.xls for original data; references [87-101]). The index 'Species per 100 stems' was computed as species per stem (total species number divided by total stem number) scaled to 100 stems. Total stem number per sample was similar between peat and mineral soils samples, $430 \pm 328$ vs $505 \pm 265$, respectively. Data compiled from $n=22$ for peat and $n=24$ for mineral areas. Richness and Fisher's alpha compared using two-tailed $\mathrm{t}$-test adjusted for unequal variance.

' Based on compilation of data on geographic range and habitat distributions from published and unpublished records for all IUCN-listed Critically Endangered (CR) plant species in Indonesia. Species shown as present in peat swamp forest are defined as all taxa with at least one record in forest reported as peat swamp forest. Species listed as present in forest on lowland mineral soils (non-swamp) are defined as all other CR species with records $<500 \mathrm{~m}$ a.s.l. minus those taxa 
that are considered specialists on azonal extreme geological features, including limestone, ultrabasic rock, or kerangas forest types that form on podzolized soils on coarse textured sedimentary rocks. Species treated as specialists on peat or mineral soils are defined as taxa with records from only one ecosystem type. A full accounting of CR species recorded as present in peat is provided in Additional File 2: Datafile_2.xls.

d Based on harp-trap inventories of insectivorous bats captured at three locations each in forests on peat in Kalimantan (Danau Sentarum, Sungai Putri, Tanjung Puting), and forests on mineral soils in Kalimantan (Barito Ulu, Sungai Lesan) and Sabah (Danum Valley). Individual captures at each site were rarefied 1000 times in EstimateS to compare species richness at a standard number of individuals ( $n=128$, the capture number in the smallest inventory at Danau Sentarum). Capture rate - total bat abundance per trapping effort at a site - is a surrogate estimate of density.

e Vertebrate densities were measured along permanent census routes in lowland forest on peat and mineral soil substrates at Gunung Palung National Park, West Kalimantan, Indonesia. Table shows total number of independent observations (Mean no. $\mathrm{km}^{2}{ }^{2}$ ) of large bodied vertebrates between August $2000-2002$ in lowland mineral areas $(\mathrm{N}=170$ surveys, $591.7 \mathrm{~km})$ and peat forest $(\mathrm{N}=87$ surveys, $290.6 \mathrm{~km})$. Species are sorted by increasing relative density on peat versus mineral soils. Note that, as this is a sample from a single site, specific values as well as presence/absence may vary substantially across sites.

fewer bat species (Table 2) and support lower densities of birds [107], bats and several keystone terrestrial and arboreal vertebrates, though not all (e.g. the orangutan, Table 2).

Second, biogeographically distinct sub-types of lowland forest on mineral soils are under-represented in Indonesia's protected area network $[108,109]$, and many existing protected areas remain threatened by illegal logging, conversion to agriculture and fires [110,111].

Third, according to 2008 data, c. 5.4 million ha of remaining lowland mineral forest in Kalimantan (25\% of the total) is zoned for conversion to non-forest agricultural uses, such as oil palm (Table 1). A further c. 12.4 million ha $(58 \%)$ is zoned as production forest, which can be legally converted to fiber plantations. Combined, more than $80 \%$ of remaining species-rich lowland forest on mineral soils in Kalimantan (c. 17.8 million ha) is eligible for conversion.

There is a risk that preferential targeting of carbondense peatland under REDD will worsen long-term prospects for biodiversity conservation in Indonesia by intensifying pressures to establish plantations in forested mineral soil areas that offer lower emission reduction potential (Table 1) but support richer biodiversity and higher concentrations of threatened species (Table 2). This problem is not unique to Indonesia [19]. Similar unintended consequences from REDD could intensify pressure on relatively low-carbon, floristically-rich cerrado ecosystems suitable for soy expansion in Brazil, and logged forests throughout the tropics, which store less carbon, but not necessarily less biodiversity than their unlogged counterparts [112,113].

\section{Safeguarding biodiversity co-benefits of REDD}

Despite meaningful progress made at COP 15 toward developing a REDD framework, it remains unclear whether and how biodiversity will be treated within REDD. A properly structured market mechanism could, in theory, promote more equal balance of REDD interventions across ecosystems with different biodiversity attributes and threat levels (see example of an auction based system in 8). In the short-term, however, such an approach would likely gain traction only in voluntary carbon markets (e.g., Gold Standard emission credits of the CCBA carbon standard, [114]), and such markets are currently too limited to have global impact [115].

Instead, we believe that a regulatory approach will be required to ensure REDD delivers substantial long-term biodiversity co-benefits in tropical countries. We make three recommendations for regulation to be effective:

\section{Recommendation 1}

Countries must prepare their own explicit national targets for ecosystem and species protection across the full range of native ecosystem types and biogeographic sub-regions (where applicable). Where such plans already exist - for example, to meet commitments under the Convention on Biodiversity (CBD) - they must be re-evaluated, updated and revised in a transparent manner, preferably in accordance with methods approved by the UNFCCC (e.g. following [116]).

\section{Recommendation 2}

Using these targets, gap analyses should be conducted to identify ecosystem types currently under-represented in the protected area network (or within degraded protected areas that have lost their conservation value) and new areas required for priority species that have insufficient habitat to maintain large viable populations. Recent work by [109] for Sumatra provides a useful model to evaluate ecosystem representation.

\section{Recommendation 3}

With co-financing from REDD to offset opportunity costs of foregone (or restricted) development, results from the above can be used to redefine acceptable landuse practices within priority areas needed to fill biodiversity conservation gaps. Examples might include: (i) re-classifying land use status of forested areas slated for conversion to non-conversion forest uses; (ii) restricting silvicultural practices in specific production forest areas to reduce impacts and maintain high biodiversity value; or (iii) re-assigning forested areas of exceptional importance for strict protection as parks or nature reserves.

If such a national planning process were made a prerequisite for multi-lateral and bi-lateral REDD funding, and REDD payments linked not only to verified emission reductions but also to biodiversity co-benefits, then net positive impacts on biodiversity would be ensured, and the negative potential impacts we describe would be reduced. A target-based approach also respects the 
sovereignty of countries to prepare their own targets, and fulfils objectives of the CBD, both for recipient (tropical) countries and donor (developed) nations who are signatories to the convention.

\section{Conclusion}

Implementing REDD to optimize biodiversity co-benefits involves trade-offs with emissions reduction and cost. At a global scale, planning REDD interventions to meet biodiversity targets, rather than maximize avoided emissions, increases estimated cost only slightly [10]. Further study is required to understand cost impacts at sub-national scales where REDD will be implemented. Spatially explicit methods are being developed to make systematic comparison among alternative land use scenarios for meeting biodiversity targets [117] and can be readily adapted to incorporate emission reduction potentials or other socio-political targets [118].

Protecting tropical forests is a good idea for mitigating global climate change and conserving globally threatened biodiversity. The devil, however, is in the details: scientists, citizens and government must work closely to determine where REDD funds should be spent to achieve an acceptable balance between emission reductions from forest and enhanced long-term biodiversity conservation.

\section{Additional material}

Additional file 1: Species richness, biomass and emission parameters for lowland forest on peat and mineral soils in Indonesia, Brunei and Malaysia. This file provides raw data and citations for information presented in tables and text of the manuscript comparing biodiversity, biomass and emission characteristics of lowland forest on peat and mineral soil substrates.

Additional file 2: Summary of REDD projects, programs and policy initiatives in Kalimantan and Sumatra, Indonesia. This file provides a summary of REDD activities in Sumatra and Kalimantan, including name, location, supporting institution(s), approximate size (ha) of areas covered by the activities and substrate (peat or mineral soils).

Additional file 3: Summary of dipterocarp tree species recorded in lowland forest on peat soils in Sumatra, Kalimantan, Sarawak and Sabah, and their conservation status on the IUCN Red List. This file provides a tabular summary of published and unpublished records for dipterocarp species recorded in at least one peat swamp forest site. Individual citations, conservation status under ICUN and some additional notes are provided for each species.

\section{Acknowledgements}

GDP, PLW and BY thank Aisyah Sileuw and staff at Daemeter Consulting for support of activities leading to the manuscript. Susan Page is acknowledged for sharing records on tree species in peat swamp. MJS was supported by a Leverhulme Trust Early Career Fellowship and wishes to thank Sephy Noerfahmy, Dorothea Pio and Tigga Kingston for sharing their bat data for biodiversity analyses. AJM thanks Universitas Tanjungpura, the Indonesian Institute of Sciences, the State Ministry of Research and Technology, the Directorate General for Nature Conservation and the Gunung Palung National Park Bureau for research permission; and J. William Fulbright Foundation, Louis Leakey Foundation, Department of Anthropology at Harvard University, and University of California at Davis for financial support.
We acknowledge Cam Webb, Antonia Gorog and Lex Hovani for useful discussions on this subject and three anonymous reviewers for constructive feedback.

\section{Author details}

${ }^{1}$ Daemeter Consulting, Bogor, Indonesia. ${ }^{2}$ People and Nature Consulting International, Jakarta, Indonesia. ${ }^{3}$ School of Archaeology and Anthropology, Australian National University, Canberra, Australia. ${ }^{4}$ Durrell Institute of Conservation and Ecology, University of Kent, Canterbury, UK. ${ }^{5}$ School of Biological \& Chemical Sciences, Queen Mary University of London, London, UK. ${ }^{6}$ Department of Anthropology, University of California at Davis, Davis, USA. ${ }^{7}$ Center for International Forestry and Agricultural Research, Bogor, Indonesia. ${ }^{8}$ Fauna and Flora International Indonesia Program, Jakarta, Indonesia. ${ }^{9}$ Xishuangbanna Tropical Botanical Garden, Chinese Academy of Sciences, Menglun, China. ${ }^{10}$ Environmental Change Institute, University of Oxford, UK. ${ }^{11}$ Global Environment Centre, Selangor, Malaysia. ${ }^{12}$ SarVision, University of Wageningen, The Netherlands. ${ }^{13}$ The Orangutan Tropical Peatland Project, Center for International Cooperation in Tropical Peatlands, Palangkaraya, Indoensia.

\section{Authors' contributions}

GDP, PLW, MJS and AJM contributed and analyzed data, and wrote the manuscript; EM, KO and BY participated in writing and the development of ideas; AT, AR, AM, BP, NW, SH and LD contributed data on biomass, plant species, emissions and/or land cover; FS contributed biomass data and the computation of Fisher's alpha for plants. All authors read and approved the final manuscript.

\section{Competing interests}

The authors declare that they have no competing interests.

Received: 10 September 2010 Accepted: 23 November 2010 Published: 23 November 2010

\section{References}

1. Metz B, Davidson O, Bosch P, Dave R, Meyer L, (eds): Climate Change 2007: Mitigation. Contribution of Working Group III to the Fourth Assessment Report of the Intergovernmental Panel on Climate Change Cambridge: Cambridge University Press; 2007.

2. van der Werf GR, Morton DC, RS DeFries, Olivier JGJ, Kasibhatla PS, Jackson RB, Collatz GJ, Randerson JT: $\mathrm{CO}_{2}$ emissions from forest loss. Nature Geoscience 2009, 2:737-738.

3. Laurance W: A new initiative to use carbon trading for tropical forest conservation. Biotropica 2007, 39:20-24.

4. IUCN: IUCN Red List of Threatened Species, Version 20102. [http://www. iucnredlist.org], Downloaded on 15 August 2010..

5. Grainger A, Boucher DH, Frumhoff PC, Laurance WF, Lovejoy T, McNeely J, Niekisch M, Raven P, Sodhi NS, Venter O, Pimm SL: Biodiversity and REDD at Copenhagen. Current Biology 2009, 19:R974-R976.

6. PEACE: Indonesia and Climate Change: Current Status and Policies. A report prepared by the World Bank, Department of International Development (DFID] and PT Pelangi Energi Abadi Citra Enviro (PEACE); 2007, 1-90 [http://siteresources.worldbank.org/INTINDONESIA/Resources/ Environment/ClimateChange_Full_EN.pdf].

7. Gurney KR, Raymond L: Targeting deforestation rates in climate change policy: a "Preservation Pathway" approach. Carbon Balance and Management 2008, 3:2.

8. Obersteiner M, Huettner MM, Kraxner F, McCallum I, Aoki K, Bottcher $H_{\text {, }}$ Fritz S, Gusti M, Havlik P, Kindermann G, Rametsteiner E, Reyers B: On fair, effective and efficient REDD mechanism design. Carbon Balance and Management 2009, 4:11.

9. Bekessy SA, Wintle BA: Using carbon investment to grow the biodiversity bank. Conservation Biology 2008, 22:510-513.

10. Venter $O$, Laurance WF, Iwamura T, Wilson KA, Fuller RA, Possingham HP: Harnessing carbon payments to protect biodiversity. Science 2009, 326:1368.

11. Strassburg BBN, Kelly A, Balmford A, Davies RG, Gibbs HK, Lovett A, Miles L, Orme CDL, Price J, Turner RK, Rodrigues ASL: Global congruence of carbon storage and biodiversity in terrestrial ecosystems. Conservation Letters 2010, 3:98-105. 
12. UNFCCC: Copenhagen accord. FCCC/CP/2009/L.7. United Nations Framework Convention on Climate Change (UNFCCC], Bonn, Germany; [http://unfccc.int/resource/docs/2009/cop15/eng/l07.pdf].

13. Venter O, Meijaard E, Possingham H, Dennis R, Sheil D, Wich S, Hovani L, Wilson K: Carbon payments as a safeguard for threatened tropical mammals. Conservation Letters 2009, 2:123-129.

14. Ebeling J, Yasué M: Generating carbon finance through avoided deforestation and its potential to create climatic, conservation and human development benefits. Philosophical Transactions of the Royal Society of London, Series B 2008, 363:1917-1924.

15. Miles $L$, Kapos $V:$ Reducing greenhouse gas emissions from deforestation and forest degradation: global land-use implications. Science 2008, 320:1454-1455.

16. Stickler CM, Nepstad D, Coe MT, McGrath DG, Rodrigues HO, Walker WS, Soares-Filho BS, Davidson EA: The potential ecological costs and cobenefits of REDD: a critical review and case study from the Amazon region. Global change Biology 2009, 15:2803-2824.

17. ATBC and STE: Association for Tropical Biology and Conservation and the Society for Tropical Ecology: The Marburg Declaration. Marburg, Germany; 2009.

18. International Monetary Fund: World Economic Outlook Database. 2010 [http://www.imf.org/external/pubs/ft/weo/2010/01/weodata/index.aspx].

19. Obidzinski K, Chaudhury M: Transition to timber plantation based forestry in Indonesia: towards a feasible new policy. International Forestry Review 2009, 2:79-87.

20. Kementerian Lingkungan Hidup: Delegasi RI: menuju industri kelapa sawit yang berkelanjutan. Press Release; 2009.

21. Post Jakarta: 18 million hectares of land for palm oil. 2009 [http://www. thejakartapost.com/news/2009/12/02/indonesia-allocates-18-millionhectares-land-palm-oil.html].

22. Jatzo F: Indonesia cutting emissions by up to 41 per cent: How? East Asia Forum 2009.

23. LOI: Letter of Intent between the Government of the Kingdom of Norway and the Government of the Republic of Indonesia on "Cooperation on reducing greenhouse gas emissions from deforestation and forest degradation". 2010 [http://www.forestsclimatechange.org/ fileadmin/photos/Norway-Indonesia-Lol.pdf].

24. Madeira EM: REDD in Design: Assessment of Planned First Generation Activities in Indonesia to Reduce Emissions from Deforestation and Degradation (REDD). RFF Discussion Paper 09-49, Resources for the Future, Washington, DC; 2009 .

25. Sills E, Madeira EM, Sunderlin WD, Wertz-Kanounnikoff S: The evolving landscape of REDD+ projects.Edited by: Angelsen A, Brockhaus M, Kanninen M, Sills E, Sunderlin WD, Wertz-Kanounnikoff S. Realising REDD+: National strategy and policy options. CIFOR, Bogor, Indonesia; 2009:265-280.

26. Jarvis A, Reuter HI, Nelson A, Guevara E: Hole-filled seamless SRTM data V4, International Centre for Tropical Agriculture (CIAT). 2008 [http://srtm. csi.cgiar.org]

27. Wahyunto S, Ritung, Subagjo H: Maps of Area of Peatland Distribution and Carbon Content in Sumatera, 1990-2002. Wetlands InternationalIndonesia Programme \& Wildlife Habitat Canada (WHC). Reproduced within Interactive Atlas of Indonesia's Forests (CD-ROM), World Resources Institute: Washington, DC; 2003.

28. Wahyunto S, Ritung, Subagjo H: Map of Peatland Distribution Area and Carbon Content in Kalimantan, 2000-2002. Wetlands InternationalIndonesia Programme \& Wildlife Habitat Canada (WHC). Reproduced within Interactive Atlas of Indonesia's Forests (CD-ROM), World Resources Institute: Washington, DC; 2005.

29. Wahyunto, Heryanto Bambang, Bekti Hasyim, Widiastuti Fitri: Maps of Peatland Distribution, Area and Carbon Content in Papua, 2000-2001 Wetlands International-Indonesia Programme \& Wildlife Habitat Canada (WHC). Reproduced within Interactive Atlas of Indonesia's Forests (CDROM), World Resources Institute: Washington, DC; 2006

30. Lawrence D: Erosion of tree diversity during 200 years of shifting cultivation in Bornean rain forest. Ecological Applications 2004 14:1855-1869.

31. Webb CO: Seedling ecology and tree diversity in a Bornean rain forest. PhD Thesis, Dartmouth College, Hanover, New Hampshire, USA.

32. Asdak C, Jarvis PG, Gardingen PV: Modelling rainfall interception in unlogged and logged forest areas of Central Kalimantan, Indonesia. Hydrology and Earth System Sciences 1998, 2:211-220.
33. Wilkie P, Argent G, Cambell E, Saridan A: The diversity of 15 ha of lowland mixed dipterocarp forest, Central Kalimantan. Biodiversity and Conservation 2004, 13:695-708.

34. Mirmanto E, Proctor J, Green J, Nagy L, Suriantata : Effects of nitrogen and phosphorus fertilization in a lowland evergreen rainforest. Philosophical Transactions of the Royal Society of London, Series B 1999, 354:1825-1829.

35. Ashton PS: Ecological studies in the mixed dipterocarp forests of Brunei State. Oxford Forestry Memoirs 25; 1964.

36. Davies SJ, Becker P: Floristic composition and stand structure of mixed dipterocarp and heath forests in Brunei Darussalam. Journal of Tropical Forest Science 1996, 8:542-569.

37. Proctor J, Anderson JM, Chai P, Vallack HW: Ecological Studies in Four Contrasting Lowland Rain Forests in Gunung Mulu National Park, Sarawak: I. Forest Environment, Structure and Floristics. Journal of Ecology 1983, 1:237-260.

38. Newbery DM, Campbell EJF, Proctor J, Still MJ: Primary lowland dipterocarp forest at Danum Valley, Sabah, Malaysia. Species composition and patterns in the understorey. Vegetatio 1996, 122:193-220.

39. Laumonier Y, Edin A, Kanninen M, Munandar AW: Landscape-scale variation in the structure and biomass of the hill dipterocarp forest of Sumatra: Implications for carbon stock assessments. Forest Ecology and Management 2010, 250:505-513.

40. Yamakura T, Hagihara A, Sukardjo S, Ogawa H: Aboveground biomass of tropical rain forest stands in Indonesian Borneo. Vegetatio 1986, 68:71-82.

41. Fox JED: A Handbook to Kabili-Sepilok Forest Reserve. Sabah Forest Record No. 9. Borneo Literature Bureau, Kuching. Sabah Forest Department; 1973.

42. Paoli GD, Curran LM, Slik JWF: Soil nutrients affect spatial patterns of aboveground biomass and emergent tree density in southwestern Borneo. Oecologia 2008, 155:287-299.

43. Lasco RD: Forest carbon budgets in Southeast Asia following harvesting and land cover change. Science in China (Series C) 2002, 45:55-64.

44. Hairiah KSM, Sitmopul M, van Noordwick, Palm C: Carbon stocks of tropical land use systems as part of the global C balance; effects of forest conversion and options for 'clean development' activities. Alternatives to Slash and Burn (ASB) Lecture Note 4a, International Center for Research in Agroforestry, Southeast Asian Regional Research Programme, Bogor, Indonesia.

45. Jaya A, Siregar UJ, Massijaya MY: Biomass content and biodiversity of peat swamp forest under various land cover conditions. Proceedings of the International Symposium on Tropical Peatland Management: Wise Use of Tropical Peatland: 14-15 July 2009; Bogor 2009.

46. Waldes N, Page SE: Forest structure and tree diversity of a peat swamp forest in Central Kalimantan, Indonesia. In Proceedings of the International Symposium on Tropical Peatland: Peatlands for People - Natural Resource Functions and Sustainable Management. Edited by: Rieley JO, Page SE. BBPT and Indonesian Peat Association; 2002:16-22.

47. Rahayu S, Lusiana B, van Noordwick M: Above ground carbon stock assessment for various land use systems in Nunukan, East Kalimantan. Edited by: Lusiana B, van Noordwick M, Rahayu S. Carbon Stock Monitoring in Nunukan, East Kalimantan: A spatial and modelling approach. World Agroforestry Center, Southeast Asia, Bogor, Indonesia; 2005:21-34.

48. Ludang Y, Palangka Jaya $\mathrm{H}$ : Biomass and carbon content in tropical forest of Central Kalimantan. Journal of Applied Sciences in Environmental Sanitation 2007, 2:7-12

49. Diemont WH, Nabuurs GJ, Rieley JO, Rijksen HD: Climate change and management of tropical peatlands as a carbon reservoir.Edited by: Rieley JO, Page SE. Biodiversity and Sustainability of Tropical Peatlands. Samara Publishing, Cardigan, U.K; 1997:363-368.

50. Brown S, Iverson LR, Prasad A, Liu D: Geographical distributions of carbon in biomass and soils of tropical Asian forests. Geocarta International 1993, 4:45-59.

51. Page SE, Banks CJ, Rieley JO: Tropical peatlands: distribution, extent and carbon storage - uncertainties and knowledge gaps. Proceedings of the International Symposium and Workshop on Tropical Peatland: carbon-climatehuman interactions on tropical peatland: carbon pools, fire, mitigation, restoration and wise use: 27-29 August 2007; Yogyakarta 2007, 19-24.

52. Agus F: Environmental risks of farming on peat land. Proceedings of International Workshop on Post Tsunami Soil Management: 1-2 July 2008; Bogor, Indonesia 2008, 65-74. 
53. Jaenicke J, Rieley JO, Mott C, Kimman P, Siegert F: Determination of the amount of carbon stored in Indonesian peatlands. Geoderma 2009, 147:151-158.

54. Melling L, Hatano R, Goh KJ: Soil CO2 flux from three ecosystems in tropical peatland of Sarawak, Malaysia. Tellus 2005, 57B:1-11.

55. Verchot LV, Petkova E, Obidzinski K, Atmadja S, Yuliani EL, Dermawan A, Murdiyarso D, Amira S: Reducing forestry emissions in Indonesia. Center for International Forestry Research (CIFOR), Bogor, Indonesia; 2010.

56. Dewi S, Khasanah N, Rahayu S, Ekadinata A, van Noordwijk M: Carbon Footprint of Indonesian Palm Oil Production: a Pilot Study. Bogor, Indonesia. World Agroforestry Centre - ICRAF, SEA Regional Office; 2009.

57. Brinkmann : Greenhouse Gas Emissions from Palm Oil Production: Literature review and proposals from the RSPO Working Group on Greenhouse Gases Final report, 9 October 2009.

58. Agus F, Runtunuwu E, June T, Susanti E, Komara H, Syahbuddin H, Las I, van Noordwijk M: Carbon dioxide emission in land use transitions to plantation. Jurnal Litbang Pertanian 2009, 28:119-126.

59. DNPI: Dewan Nasional Perubahan Iklim Indonesia: Indonesia Greenhouse Gas Abatement Cost Curve. Jakarta; 2010 [http://www.dnpi.go.id/report/ DNPI-Media-Kit/reports/indonesia-ghg_abatement_cost_curve/ Indonesia_ghg_cost_curve_english.pdf].

60. Hooijer A, Silvius M, Wösten H, Page S: PEAT-CO2, Assessment of CO2 emissions from drained peatlands in SE Asia. Delft Hydraulics report Q3943 (2006); 2006, 1-41

61. Hooijer A, Page S, Canadell JG, Silvius M, Kwadijk J, Wosten H, Jauhiainen J: Current and future $\mathrm{CO}_{2}$ emissions from drained peatlands in Southeast Asia. Biogeosciences 2010, 7:1505-1514.

62. Andriesse JP: Nature and Management of Tropical Peat Soils. FAO Soils Bulletin, 59. Rome; 1988

63. Holmes D: Indonesia: Where Have All the Forests Gone? Environment and Social Development, East Asia and Pacific Region Discussion Paper. World Bank, Washington, DC; 2002, 1-52

64. Mutert $\mathrm{E}$, Fairhurst TH, von Uexkull HR: Agronomic management of oil palms on deep peat. Better Crops International 1999, 13:22-27.

65. Sargeant HJ: Vegetation Fires in Sumatra, Indonesia Oil Palm Agriculture in the Wetlands of Sumatra. Destruction or Development? European Union and Ministry of Forestry, Jakarta, Indonesia; 2001.

66. Miettinen J, Liew SC: Degradation and development of peatlands in Peninsular Malaysia and in the islands of Sumatra and Borneo since 1990. Land Degradation and Development 2010, 21:285-296.

67. Herzog T: World Greenhouse Gas Emissions in 2005. WRI Working Paper World Resources Institute, Washington, DC; 2009, 1-5.

68. Page SEF, Siegert JO, Rieley, Boehm HDV, Jaya A, Limin S: The amount of carbon released from peat and forest fires in Indonesia during 1997. Nature 2002, 420:61-65.

69. Ministry of Forestry (MoF): Forestry statistics of Indonesia. Department of Forestry, Ministry of Forestry, Jakarta, Indonesia; 2009.

70. Simamora AP: Stop converting peatlands, govt study recommends. The Jakarta Post, Jakarta; 2010 [http://www.thejakartapost.com/news/2010/01/ 18/stop-converting-peatlands-govt-study-recommends.html], 18 January 2010.

71. Gaveau DLA, Wich S, Epting J, Juhn D, Kanninen M, Leader-Williams N: The future of forests and orangutans (Pongo abelii) in Sumatra: predicting impacts of oil palm plantations, road construction, and mechanisms for reducing carbon emissions from deforestation. Environmental Research Letters; 2009:4:11.

72. Joppa LN, Pfaff A: High and far: biases in the location of protected areas. PLOS ONE 2009, 4:e8273.

73. Ng PKL, Tay JB, Lim KKP: Diversity and conservation of blackwater fishes in Peninsular Malaysia, particularly in the North Selangor peat swamp forest. Hydrobiologia 1994, 285:203-218.

74. Kottelat M, Whitten T: Freshwater biodiversity in Asia: with special reference to fish. World Bank Technical Paper No 343 World Bank, Washington DC; 1996.

75. Page SE, Rieley JO, Doody K, Hodgson S, Husson S, Jenkins P, MorroghBernard H, Otway S, Wilshaw S: Biodiversity of tropical peat swamp forest: A case study of animal diversity in the Sungai Sebangau catchment of Central Kalimantan, Indonesia. In Tropical peatlands. Edited by: Rieley JO, Page SE. Cardigan: Samara Publishing Limited; 1997:231-242.
76. Wikramanayake E, Dinerstein E, Loucks JC, Olson MD, Morrison J, Lamoreux J, McKnight M, Heda P: Terrestrial Ecoregions of the Indo-Pacific. A Conservation Assessment USA: Island Press; 2002.

77. Meijaard E: The importance of swamp forest for the conservation of orang utans (Pongo pygmaeus pygmaeus) in Kalimantan, Indonesia. In Proceedings of the International Symposium on the Biodiversity, Environmental Importance and Sustainability of Tropical Peat and Peatlands. Edited by: Page SE, Rieley JO. Samara Publishing Limited; 1997:243-254.

78. Bezuijen M, Webb GJW, Hartoyo P, Samedi : Peat swamp forest and the false gharial Tomistoma schlegelii (Crocodilia, Reptilia) in the Merang River, eastern Sumatra, Indonesia. Oryx 2001, 35:301-307.

79. Uryu Y, et al: Deforestation, degradation, biodiversity loss and $\mathrm{CO}_{2}$ emission in Riau, Sumatra, Indonesia. WWF Technical Report, Jakarta Indonesia; 2008.

80. Husson SJ, Wich SA, Marshall AJ, Dennis RD, Ancrenaz M, Brassey R, Gumal M, Hearn AJ, Meijaard E, Simorangkir T, Singleton I: Orangutan distribution, density, abundance and impacts of disturbance. In Orangutans: Geographic variation in behavioral ecology and conservation. Edited by: Wich SA, Utami S, Mitra Setia T, van Schaik CP. Oxford: Oxford University Press; 2009:77-96.

81. Whitmore TC: Tropical rain forests of the Far East. 2 edition. Oxford: Oxford University Press; 1984.

82. IUCN: The conservation atlas of tropical forests: Asia and the Pacific London: Macmillan; 1991

83. Ashton PS: Conservation of Borneo biodiversity: do small lowland parks have a role, or are big inland sanctuaries sufficient? Brunei as an example. Biodiversity and Conservation 2009, 19:343-356.

84. Janzen DH: Tropical blackwater rivers, animals, and mast fruiting by the Dipterocarpaceae. Biotropica 1974, 6:69-103.

85. Mirmanto E, Polosokan R: Preliminary study on growth, mortality and recruitment of tree species in peat swamp forest at Tanjung Puting National Park, Central Kalimantan. In Proceedings of the International Symposium on Tropical Peat Lands. Edited by: Rieley JO, Banks CJ, Ragjagukguk B. Hokkaido University 1999:165-172.

86. Nishimua TB, Suzuki E, Kohyama T, Tsuyuzaki S: Mortality and growth of trees in peat-swamp and heath forests in Central Kalimantan after severe drought. Plant Ecology 2006, 193:301-313.

87. Purwaningsih, Yusuf R: Vegetation Analysis of Suaq Belimbing peat swamp Forest, Gunung Leuser National Park-South Aceh. Proceedings of the International Symposium on Tropical Peat Lands Hokkaido University \& Indonesian Institute of Sciences. Bogor, Indonesia; 1999, 275-282.

88. Siregar M, Sambas EN: Composition of Peat Swamp Forest in MensematSambas, West Kalimnatan. Proceedings of the International Symposium on Tropical Peat Lands Hokkaido University \& Indonesian Institute of Sciences. Bogor, Indonesia; 1999, 153-164.

89. Saribi AH, Riswan SS: Peat swamp forest in Nyaru Menteng Arboretum, Palangkaraya, Central Kalimantan, Indonesia: Its tree species diversity and secondary succession. Paper presented at the Seminar on Tropical Ecology held by Japanese Society of Tropical Ecology, 21-22 June 1997, Shiga, Japan .

90. Yamada I: Peat swamp forests in Borneo and Sumatra - Original state, development and disasters during the past 50 years with a proposal for future eco-resource management. Tropics 2006, 15:329-336.

91. Santosa Y, Kartono AP, Muin A: Pendugaan potensi dan studi keanekaragaman jenis vegetasi di calon lokasi pelepas-liaran orang utan di Kabupaten Seruyan, Propinsi Kalimantan Tengah. Report for Orangutan Foundation International and Infinite Earth Rimba Raya Project; 2008.

92. Anderson JAR: The ecology and forest types of the peat swamp forests of Sarawak and Brunei in relation to their silviculture. PhD Dissertation, Edinburgh, England; 1961.

93. Anderson JAR: The flora of the peat swamps of Sarawak and Brunei, including a catalogue of all recorded species of flowering plants, ferns and fern allies. The Gardens Bulletin, Singapore 1963, 20:131-228.

94. Anderson JAR: The tropical peat swamps of western Malaysia. Mires: Swamp, Bog, Fen and Moot: Ecosystems of the World 4B, Elsevier, Amsterdam; 1983, 181-199.

95. Cannon C, Leighton M: Tree species distributions across five habitats in a Bornean rain forest. Journal of Vegetation Science 2004, 15:257-266. 
96. Eichhorn KAO, Slik JWF: The plant community of Sungai Wain, East Kalimantan, Indonesia: Phytogeographical status and local variation. Blumea Supplement 2006, 18:15-35.

97. Miyagi Y, Tagawa H, Suzuki E, Wirawan N, Oka NP: Phytosociological study on the vegetation of Kutai National Park, East Kalimantan, Indonesia. Memorial Kagoshima University Research Center, Occasional Papers 1988, 14:51-62.

98. van Valkenburg JLCH: Non-Timber Forest Products of East Kalimantan. Potentials for Sustainable Use. Tropenbos Series 16. The Tropenbos Foundation, Wageningen, The Netherlands; 1997.

99. Kitayama K: An altitudinal transect study of the vegetation on Mount Kinabalu, Borneo. Vegetatio 1992, 102:149-171.

100. Pendry CA, Proctor J: Altitudinal zonation of rain forest on Bukit Belalang, Brunei: soils, forest structure and floristics. Journal of Tropical Ecology 1997, 13:221-241.

101. Ashton PS: Dipterocarpaceae. Flora Malesiana; 19829, Series 1.

102. Newman MF, Burgess PF, Whitmore TC: Royal Botanic Garden Edinburgh. Borneo Island Medium and Heavy Hardwoods: Dipterocarpus, Drybalanops, Hopea, Shorea (balau/selangan batu), Upuna United Kingdom: The Charlesworth Group; 1998.

103. Newman MF, Burgess PF, Whitmore TC: Royal Botanic Garden Edinburgh. Borneo Island Light Hardwoods: Anisoptera, Parashorea, Shorea (red, white and yellow meranti) United Kingdom: The Charlesworth Group; 1998.

104. Laumonier Y: Geobotany 22. The vegetation and physiography of Sumatra Netherlands: Kluwer Academic Publishers; 1997.

105. Simbolon H, Mirmanto E: Checklist of plant species in the peat swamp forests of Central Kalimantan, Indonesia. Proceedings of the International Symposium on Tropical peatlands, 22-23 November 1999; Bogor University of Hokkaido \& Indonesian Institute of Sciences; 2000, 179-190.

106. Purwaningsih : Sebaran ekologi jenis-jenis Dipterocarpaceae di Indonesia. Biodiversitas 2004, 5:89-95.

107. Gaither JC: Understorey avifauna of a Bornean peat swamp forest: Is it depauperate? Wilson Bulletin 1994, 106:381-390.

108. Mackinnon J: Protected areas systems review of the Indo-Malayan Realm. The Asian Bureau for Conservation and World Conservation Monitoring Center; Cambridge: Call Printers Limited; 1997.

109. Laumonier Y, Uryu Y, Stüwe M, Budiman A, Setiabudi B, Hadian O: Ecofloristic sectors and deforestation threats in Sumatra: identifying new conservation area network priorities for ecosystem-based land use planning. Biodiversity and Conservation 2010, 19:1153-1174.

110. Curran LM, Trigg SN, McDonald AK, Astiani D, Hardiono YM, Siregar P, Caniago I, Kasischke E: Lowland forest loss in protected areas of Indonesian Borneo. Science 2004, 303:1000-1003.

111. Gaveau DLA, Epting J, Lyne O, Linkie M, Kumara I, Kanninen M, LeaderWilliams N: Evaluating whether protected areas reduce tropical deforestation in Sumatra. Journal of Biogeography 2009, 11:2165-2175.

112. Cannon $\mathrm{CH}$, Peart $\mathrm{DR}$, Leighton $\mathrm{M}$ : Tree species diversity in commercially logged Bornean rainforest. Science 1998, 281:1366-1368.

113. Meijaard E, Sheil D, Nasi R, Augeri D, Rosenbaum B, Iskandar D, Setyawati T, Lammertink MJ, Rachmatika I, Wong A, Soehartono T, Stanley S, O'Brien T: Life after logging: reconciling wildlife conservation and production forestry in Indonesian Borneo CIFOR, WCS and UNESCO, Bogor, Indonesia; 2005.

114. CCBA: Climate, Community \& Biodiversity Project Design Standards, Second Edition CCBA. Arlington, VA; 2008, 1-50 [http://www.climatestandards.org]

115. Karousakis K: Promoting biodiversity co-benefits in REDD. OECD Publishing; 2010, 1-26, OECD Environment Working Papers, No 11

116. Pressey RL, Humphries CJ, Margules CR: Beyond opportunism-key principles for systematic reserve selection. Trends in Ecology \& Evolution 1993, 8:124-128.

117. Wilson K, Meijaard E, Drummond S, Grantham H, Boitani L, Catullo G, Christie L, Dennis R, Dutton I, Falcucci A, Maiorano L, Possingham H, Rondinini C, Turner W, Venter O, Watts M: Conserving biodiversity in production landscapes. Ecological Applications 2010, 20:1721-1732.

118. Ghazoul J, Butler RA, Mateo-Vega J, Koh LP: REDD: a reckoning of environment and development implications. Trends in Ecology and Evolution 2010, 25:396-402.

doi:10.1186/1750-0680-5-7

Cite this article as: Paoli et al:: Biodiversity Conservation in the REDD.

Carbon Balance and Management 2010 5:7.

\section{Submit your next manuscript to BioMed Central and take full advantage of:}

- Convenient online submission

- Thorough peer review

- No space constraints or color figure charges

- Immediate publication on acceptance

- Inclusion in PubMed, CAS, Scopus and Google Scholar

- Research which is freely available for redistribution 